\title{
Influence of water restriction on the performance and organ development of young broilers
}

\author{
Teresa Herr Viola ${ }^{1}$, Andréa Machado Leal Ribeiro², Antônio Mário Penz Júnior², Eduardo \\ Spillari Viola ${ }^{1}$
}

\footnotetext{
${ }^{1}$ Programa de Pós-Graduação em Zootecnia, UFRGS, Brasil.
}

2 Departmento de Zootecnia, UFRGS, Brasil.

\begin{abstract}
The experiment was carried out to evaluate the effect of $0 \%, 10 \%, 20 \%, 30 \%$, and $40 \%$ water restriction (WR) on broiler performance, behavior, organ development (heart, leg, proventriculus and gizzard, liver, and intestines), and intestinal micrometry. Four hundred and eighty ROSS 308 male broilers were raised in battery cages measuring $0.72 \mathrm{~m}^{2}$, from 1 to 21 days of age. Feed was offered ad libitum, and environmental temperatures were kept in thermoneutral conditions. Water intake was estimated based on a control group, two days older than the experimental birds, with same initial weight. A linear reduction on bird performance, duodenal villi height, and fresh organs weight were observed as WR increased. At 21 days of age, for each $1 \% \mathrm{WR}$, a weight loss of $8.5 \mathrm{~g}$ was observed. However, the mortality rate was not affected by any WR level. Organ weight, relative to body weight, was not affected by WR, except for heart, which weight increased with WR. Villi numbers and crypts depth were not affected by WR. Birds under WR changed their behavior, becoming aggressive and irritated. Electron microscopy data showed higher villi extrusion in WR broilers. In conclusion, WR, regardless its magnitude, should be avoided in broiler production.
\end{abstract}

Key Words: behavior, chickens, duodenal morphology and histology, organs, water

\section{Influência da restrição de água no desempenho e no desenvolvimento dos órgãos de frangos de corte}

RESUMO - Avaliou-se a influência da restrição de água (0,10, 20, 30 e 40\%) no desempenho, no comportamento e desenvolvimento de orgãos (coração, perna, proventrículo e moela, fígado e intestinos) e na micrometria intestinal de frangos de corte. Utilizaram-se 480 machos, linhagem ROSS 308 , do $1^{\circ}$ ao $21^{\circ}$ dia de idade, criados em gaiolas de $0,72 \mathrm{~m}^{2}$. As aves receberam dieta basal à vontade e foram mantidas em temperatura de conforto térmico. O consumo de água foi estimado em um grupo de aves controle, dois dias mais velhas que as aves experimentais, porém com o mesmo peso inicial. As medidas de desempenho foram tomadas semanalmente e o consumo de água, diariamente. Aos 21 dias, 18 aves por nível de restrição (tratamento) foram sacrificadas para realização das medidas de micrometria intestinal (6 aves) e do peso de órgãos (12 aves). Diariamente, observou-se o comportamento das aves durante o período de fornecimento da água. O desempenho das aves, a altura das vilosidades duodenais e os pesos frescos dos órgãos reduziram de forma linear de acordo com o aumento da restrição de água. Aos 21 dias de idade, a cada $1 \%$ de restrição de água, houve perda de $8,5 \mathrm{~g}$ no ganho de peso. No entanto, a mortalidade não foi afetada por qualquer nível de restrição de água. Não foi encontrada diferença na profundidade de cripta, no número de vilos e no peso relativo dos orgãos (em relação ao peso corporal), exceto do coração, que aumentou com a restrição de água. Nas aves sob restrição de água, houve maior extrusão dos vilos. Os frangos submetidos à restrição de água alteraram seu comportamento, tornando-se agressivos e irritadiços. A restrição de água, independentemente de sua magnitude, deve ser evitada na criação de frangos de corte.

Palavras-chave: água, comportamento, frango de corte, morfologia e histologia duodenal, órgãos

\section{Introduction}

Water is considered the most important nutrient for animals. While growth rate, uniformity and health are common problems in commercial production, water quality and consumption are usually not taken into consideration (Counotte, 2003). Water intake per animal and feed intake:water consumption ratios of modern broiler genetic strains are higher when compared to non-selected broilers. The growth rate capacity of modern broiler strains (around 
55 to $60 \mathrm{~g} /$ day) makes water essential. Water restriction reduces broiler performance (Bruno \& Macari, 2002). Marks (1981) compared non-selected and selected fast growing commercial strain broilers (Cobb) and observed that water intake was higher for the fast growing strain, with feed and water provided ad libitum. The selected strain broilers, restricted to the same water intake as that of the nonselected strain broilers, presented worse feed conversion. These findings indicate that water intake may play a major role in facilitating the genetic potential for growth. Kellerup et al. (1965) observed water restriction effects in broilers from one to eight weeks of age. Body weight and feed consumption decreased with each water restriction increment, but the mortality rate was not significant among restriction levels (up to 50\%). When ad libitum in water intake was reduced in 20 percent or more, feed conversion was impaired. Age and increments in water restriction levels reduced the water:feed consumption ratio.

Water restriction is related to a typical stress behavior, with muscular motility coordination, modulated directly or not by the neuroendocrine system (Zulkilfi \& Siegel, 1995). Bieres et al. (1965) observed that water deprivation for 12 hours or more had adverse effects on the chick growth performance. Since birds are different in their ability to conserve body water by increasing kidney resorption, it is possible to cause dehydration in some birds by practicing water restriction in a flock (NRC, 1994). Arad (1983) observed that, after 48 hours of water deprivation, dehydrated birds presented slightly higher body temperature when compared to normally hydrated birds. Dehydrated fowls were capable of recovering $92 \%$ of the initial body weight within 30 min of drinking. However, birds that lost more than $15 \%$ of their weight failed to recover it. In addition, since feed intake is related to water intake, any factor interfering with feed intake affects water intake (Macari, 1995).

The objective of this experiment was to evaluate the effect of four water supply levels on broiler performance, behavior, development of legs, heart, proventriculus and gizzard, liver and intestines, and duodenal histology and morphology by scanning electron microscopy.

\section{Material and Methods}

Four hundred and eighty Ross 308 male chicks were submitted to five treatments based on water restriction during a 21-day experimental period. The following treatments were applied: $100 \%$ - ad libitum water supply; $90 \%-90 \%$ daily water supply (10\% restriction); $80 \%-80 \%$ daily water supply (20\% restriction); $70 \%-70 \%$ daily water supply (30\% restriction); 60\%-60\% daily water supply (40\% restriction). The experiment was carried out in an environmentally controlled room, and the birds were housed in battery cages measuring $0.72 \mathrm{~m}^{2}$ equipped with feeders and baby drinkers (one per cage). A randomized complete block design was used, with five treatments and six replicates of 14 chickens per treatment. The blocks were established based on the initial body weight. According to that, chicks were divided into three weight groups (light - below $44.3 \mathrm{~g}$, intermediate- between 44.4 and 47.2 , and heavy- above $47.3 \mathrm{~g}$ ).

Ad libitum water supply was estimated based on a control group of six replicates of 10 chicks per replicate. The control group was housed in battery cages in the same room, two days before the beginning of the experiment. The chicks had the same initial weight as the experimental ones. Water consumption in this group was used as reference to establish the amount of water to be supplied to birds from the restricted treatments. In the restricted treatments, water was supplied once a day, around 12:00 am. The chick behavior was daily observed during water supply and for the next two hours.

The same diet was offered ad libitum to chicks from all treatments. It contained $22 \%$ of crude protein, $3100 \mathrm{kcal} / \mathrm{kg}$ of AME, $1.26 \%$ of Total Lys , $0.94 \%$ of Total Met-Cys, $1.0 \%$ of Calcium, and $0.5 \%$ of available Phosphorus. Chicks were provided 24 hours of light, and the room temperature was adjusted according to the ROSS 308 manual (AgRoss, 2000).

Feed intake (FI), weight gain (WG) and feed conversion ratio (FCR) were weekly evaluated, whereas water consumption (WC) was daily evaluated. At 21 days of age, two chickens per replicate were sacrificed, and heart, liver, proventriculus+gizzard (P+gizzard), small+large intestine, and deboned leg were collected and weighed. Relative organ weight was calculated by dividing the weight of the part by the bird's body weight. The dry matter content of organs and legs was determined (AOAC, 1993).

A third chicken per replicate was sacrificed to collect two centimeters of the duodenum, at the pancreatic region. The sample was washed with de-ionized water and kept in plastic flasks, with buffered formalin at $10 \%$ in order to determine villi number (VN), villi height (VH), and crypt depth (CD). Also, at 7, 14 and 21 days of age, the duodenum of a fourth chicken was collected, washed with de-ionized water, and the samples were prepared for electron microscopy reading.

Data were analyzed through ANOVA and regression analysis, and the means were compared by Tukey test (SAS, 2000). 


\section{Results and Discussion}

The water consumption between chicks from the control group and chicks receiving water ad libitum were compared and no differences were observed. Therefore, keeping birds with the same initial weight, but two days older than the experimental group resulted in an acceptable way to estimate the water intake.

The different chick initial weights (blocks) did not show significant effect in any analysis.

Weekly data are not presented because the responses were quite similar to data obtained for the total experimental period (1 to 21 days). Water restriction caused severe reduction in broiler performance, as demonstrated in Table 1. Data show a linear reduction $(\mathrm{P}<0.0001)$ of feed intake $(\mathrm{FI})$ and weight gain (WG) as water restriction increased. As demonstrated through the regression equation, for each $1 \%$ of water restriction, $8.5 \mathrm{~g}$ of body weight were lost within 21 days. Nilipoul \& Butcher (1998) demonstrated that water-restricted chickens, even if restricted for few hours, stop growing.

The feed conversion ratio also presented linear increase as water restriction levels increased. However, the determination coefficient of the regression analysis was lower than those of the other variables. The Tukey test also showed that increases on the water restriction levels did not have a clear relationship with FCR. Restriction levels of 10, 30, and 40\% resulted in equal FCR. Kellerup et al. (1965) found no differences in FCR either, when chickens were submitted to $10 \%$ of water restriction. These researchers observed that chickens submitted to 20 and $30 \%$ of water restriction showed significant performance differences only at the $7^{\text {th }}$ week of age. However, when 40 and $50 \%$ of water restriction was applied, differences were already observed at the $4^{\text {th }}$ week of age. These contradictory data may be related to one of the most important factors interfering with water consumption, which is genetics (Penz \& Vieira, 2002). Modern strains are very different from the strain used by Kellerup et al. (1965), with a higher weight gain capacity. Each day of water restriction is meaningful for the performance of modern broilers due to the lower number of days required for birds to be ready for market.

The water restriction did not affect chicken livability. These results are consistent with those found by Kellerup et al. (1965). In fact, birds tried to adapt themselves to adverse conditions. Although the absolute weight of all organs and legs was reduced in function of the increment of water restriction levels (data not shown), Table 2 shows that when the water supply levels decreased, no difference
Table 1 - Water consumption (WC), feed intake (FI), weight gain (WG) and feed conversion ratio (FCR) of broilers submitted to different water supply levels from 1 to 21 days of age

\begin{tabular}{lcccc}
\hline Treatment & WC $(\mathrm{mL})$ & FI $(\mathrm{g})$ & WG $(\mathrm{g})$ & FCR $(\mathrm{g} / \mathrm{g})$ \\
\hline $100 \%$ & 2295 & $1077 \mathrm{a}$ & $823 \mathrm{a}$ & $1.31 \mathrm{c}$ \\
$90 \%$ & 2066 & $988 \mathrm{~b}$ & $697 \mathrm{~b}$ & $1.42 \mathrm{~b}$ \\
$80 \%$ & 1836 & $877 \mathrm{c}$ & $611 \mathrm{c}$ & $1.44 \mathrm{ab}$ \\
$70 \%$ & 1605 & $788 \mathrm{~d}$ & $517 \mathrm{~d}$ & $1.53 \mathrm{a}$ \\
$60 \%$ & 1377 & $697 \mathrm{e}$ & $487 \mathrm{~d}$ & $1.43 \mathrm{ab}$ \\
VC $(\%)$ & & 5.5 & 6.0 & 4.1 \\
Prob.SF & & 0.0001 & 0.0001 & 0.0003 \\
\hline
\end{tabular}

Averages followed by different letters in the same column are different $(\mathrm{P}<0.05)$ by Tukey test.

$\mathrm{FI}=9.6 \mathrm{x}+117.53, \mathrm{R}^{2}=0.88, \mathrm{P}<0.0001$.

$\mathrm{WG}=8.51 \mathrm{x}-53.5, \mathrm{R}^{2}=0.90, \mathrm{P}<0.0001$.

$\mathrm{FCR}=-.004 \mathrm{x}+1.71, \mathrm{R}^{2}=0.29, \mathrm{P}<0.002$.

was observed in tissue weights in relation to the body weight. Data indicated that the reduction in tissue weight was proportional to the reduction in body weight, regardless the water restriction level. Only heart relative weight $(\mathrm{HW})$ increased as water supply levels decreased. These results may be explained by the higher blood viscosity caused by water restriction. This phenomenon was visually observed when birds were sacrificed. Buhr et al. (1998) studied the effect of feed restriction and observed opposite results.

In terms of dry matter, only the leg dry matter increased with water restriction, regardless the supply level $(24.8 \% \mathrm{x}$ $26.4 \%$ ). Davis et al. (1988) observed in newly-hatched chicks that leg skin is the area that undergoes the fastest dehydration when compared as to other areas and it is used as an emergency water source during osmotic stress periods, when water is lacking. Although not found in literature for older broilers, this phenomenon may explain the results observed.

Another evidence of coping was that treatments did not affect the water intake: feed intake ratios, which were always $2: 1$, regardless the water supply level. These ratios are the same as those reported in literature (NRC, 1994).

When water is offered ad libitum, chickens develop a very characteristic feed intake pattern. However, this pattern can change according to the water availability and management (Macari, 1995). In this experiment, chickens submitted to water restriction showed a non-conventional behavior, which was maintained during the entire experimental period. Without water, chickens did not eat and were sleepy, regardless the supply level. Water restriction can increase heart rate, respiratory frequency, cloacal temperature, in addition of causing sleepiness, pain at the body extremities, blood concentration increase, blood volume 
Table 2 - Relative organ and leg weights of 21-day-old broilers submitted to different water supply levels

\begin{tabular}{lccccc}
\hline Treatment & \multicolumn{5}{c}{ Percentage in relation to the total body weight $(\%)$} \\
\cline { 2 - 6 } & Heart $(\mathrm{HW})$ & Leg ${ }^{1}$ & Liver & Intestine & P+Gizzard $^{2}$ \\
\hline $100 \%$ & 0.61 & 3.16 & 2.76 & 3.88 & 2.85 \\
$90 \%$ & 0.66 & 3.02 & 2.77 & 4.01 & 3.89 \\
$80 \%$ & 0.67 & 3.26 & 2.71 & 4.16 & 3.08 \\
$70 \%$ & 0.68 & 3.11 & 2.85 & 3.07 \\
$60 \%$ & 0.68 & 3.18 & 2.71 & 12.9 & 3.24 \\
VC $(\%)$ & 9.7 & 7.7 & 0.1 & 0.61 & 0.08 \\
ProbF & 0.06 & 0.20 & &
\end{tabular}

${ }^{1}$ Relative weight of one single leg.

2 Proventricullus+gizzard.

Averages followed by different letters in the same column are different by Tukey test.

$\mathrm{HW}=-0.0016 \mathrm{x}+0.79, \mathrm{R}^{2}=0.11, \mathrm{P}<0.01$.

reduction, and blood circulation reduction. These effects may cause nausea and appetite reduction (Lloyd et al., 1978). In the present study, in the presence of humans, the birds were excited, running, and jumping into the cages. When water was offered to birds, some started to peck other chicken's toes. When water-restricted chickens received water, they tried to drink it all very fast, in approximately two hours, regardless the restriction levels. It was possible to observe that the limit of water consumption was the crop size, which was enlarged. Chicks usually consumed feed after drinking. However, they frequently regurgitated water due to the presence of feed. After satisfied of water, birds were often seen watering their bodies. After eating, they started to produce excreta within two hours, in two separated forms (solid excreta and water, showing a rapid water transit and a possible decrease in its absorption). Lloyd et al. (1978), Yu et al. (1990), and Brooks (1994) also described similar behaviors in chickens submitted to water restriction.

Water restriction did not affect villi number and crypt depth. However, there was a linear reduction in villi height (Table 3). Dibner et al. (1996), Geyra et al. (2001), and Penz \& Vieira (2002) reported that feed nutrients are essential for mucosa metabolism. Since water restriction leads to a feed restriction, a decrease nutrient supply to the intestine is expected. Villi height is associated with a larger absorptive surface due to the higher number of enterocytes capable of absorbing nutrients (Geyra et al., 2001).

Based on scanning electron microscopy, seven-dayold chicks submitted to water restriction showed cells extrusion from apices villi. This fact could be explained by the higher abrasive affect of the diet on the villi surface in water-restricted birds (Figure 1). At 14 and 21 days of age, the differences were more significant and increased as the water supply levels decreased (Figure 2). The villi of chicks not submitted to water restriction had a smooth surface, and
Table 3 - Villi number and height, and crypt depth of 21-day-old chickens submitted to different water supply levels

\begin{tabular}{lccc}
\hline & \multicolumn{3}{c}{ Histological analysis $(\mathrm{mm})$} \\
\cline { 2 - 4 } & Villi number (VN) & Villi height (VH) & Crypt \\
\hline $100 \%$ & 10.9 & $1657 \mathrm{a}$ & 101 \\
$90 \%$ & 10.8 & $1595 \mathrm{ab}$ & 102 \\
$80 \%$ & 10.8 & $1501 \mathrm{ab}$ & 107 \\
$70 \%$ & 10.8 & $1376 \mathrm{~b}$ & 112 \\
$60 \%$ & 11.0 & $1364 \mathrm{~b}$ & 110 \\
$\mathrm{CV}(\%)$ & 11.6 & 10.0 & 19.1 \\
Prob>F & .99 & .013 & .83 \\
\hline
\end{tabular}

Averages followed by different letters in the same column are different by Tukey test.

$\mathrm{VH}=8.05 \mathrm{x}+854.58, \mathrm{R}^{2}=0.41, \mathrm{P}<0.0001$.
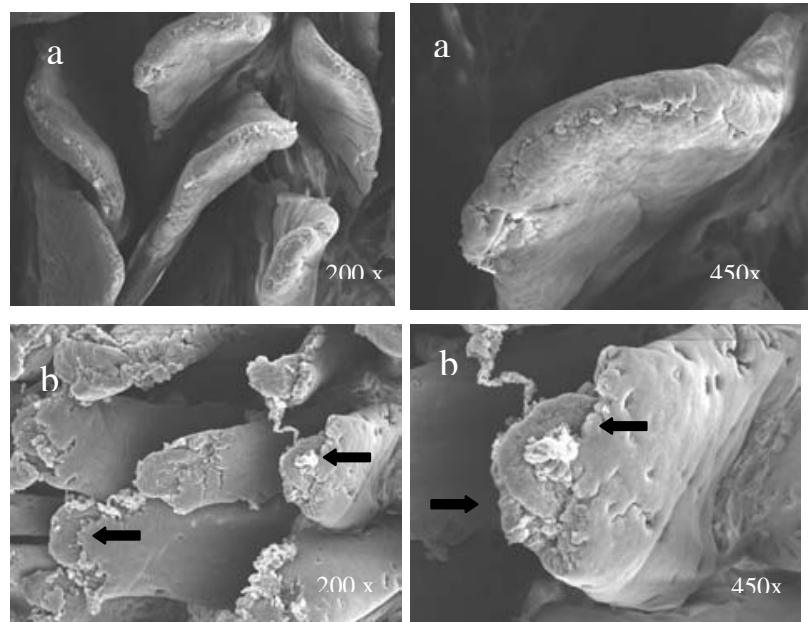

Figure 1 - a. Duodenal villi of a 7-day-old control chicken. b. Villi of a 7-day-old water-restricted chicken. 


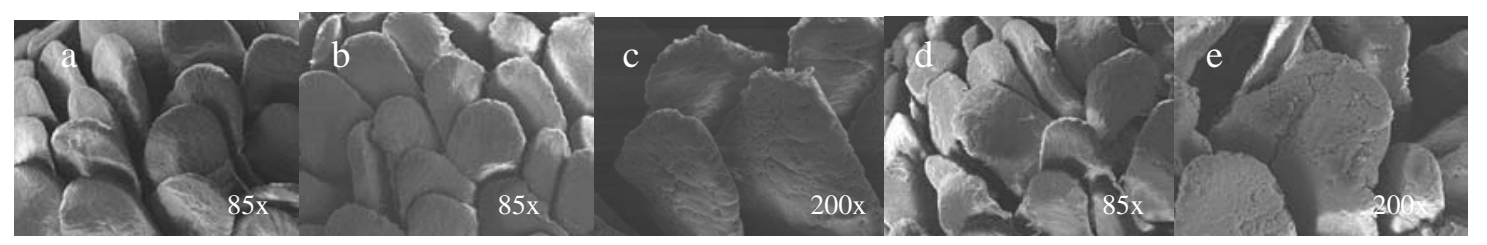

Figure 2 - Duodenal villi of chicks at 21 days of age submitted to the following treatments: a) $100 \%$ of water supply; b) $90 \%$ of water supply; c) $80 \%$ of water supply; d) $70 \%$ of water supply; e) $60 \%$ of water supply.

the tip was round. The villi of water-restricted chickens presented damaged surface, with long tips, less turgid texture, and were thinner, causing tip extrusion.

\section{Conclusions}

Water must be considered as an essential nutrient since its restriction caused reduction in feed intake and weight gain and increase in the feed conversion ratio in broilers reared from 1 to 21 days. On the other hand, water restriction up to $40 \%$ did not increase the mortality rate of birds kept under thermoneutral conditions. Water restriction did not reduce the weight of most of the organs as a proportion of the body weight, except for heart, which weight increased. Water restriction reduced the villi height, but did not affect the villi number or crypt depth.

It is suggested that in further experiments on water restriction, water should be offered often (more than once a day) in order to prevent water spillage.

\section{Literature Cited}

AGROCERES ROSS. Manual de manejo de frangos AgRoss. Campinas: Melhoramento Genético de Aves S.A., 2000. 56p. ASSOCIATION OF OFFICIAL AGRICULTURAL CHEMISTS AOAC. Official Methods and Recommended Practices of American Oil Chemists Society. 4.ed. Washington, 1993. v.1.

ARAD, Z. Thermoregulation and acid-base status in the painting dehidrated fowl. Journal of Applied Physiology, v. 54, p.234$243,1983$.

BIERES, B.W.; ELEAZER, T.H.; ROEBUCK, D.E. Effects of feed and water deprivation on chickens of various ages. Poultry Science, v.44, p.1351-1355, 1965.

BROOKS, P.H. Water: forgotten nutrient and novel delivery system. In: ALLTECH'S ANNUAL SYMPOSIUM, 10., 1994, Nicholasville. Proceedings... Nicholasville: Alltech Technical Publication, 1994. p.211-234.

BRUNO, L.D.G.; MACARI, M. Ingestão de água: mecanismos regulatórios. In: MACARI, M.; FURLAN, R.L.; GONZALES, E. (Eds.) Fisiologia aviária aplicada a frangos de corte. 2.ed. Jaboticabal: FUNEP, 2002. p.201-208.
BUHR, R.J.; NORTHCUTT, J.K.; LYON, C.E. et al. Influence of time off feed on broiler viscera weight, diameter and shear. Poultry Science, v.77, p.758-764, 1998.

COUNOTTE, G. Avicultura profesional: conocer la calidad del água de bebida. Doetinchem: Reed Business Information, 2003. p.20-22.

DAVIS, T.A.; SHEN, S.S.; ACKERMAN, R.A. Embrionic osmorregulation: consequences of hight and low water loss during incubation of the chicken egg. Journal of experimental Zoology, v.245, n.2, p.144-156, 1988.

DIBNER, J.J.; KITCHELL, M.L.; ATWELL, C.A. et al. The effect of dietary ingredients and age on the microscopic structure of the gastrointestinal tract in poultry. Journal of Applied Poultry Research, v.5, p.70-77, 1996.

GEYRA, A.; UNI, Z.; SKLAN, D. Enterocyte dynamics and mucosal development in the posthatch chick. Poultry Science, v.80, p.776-782, 2001.

KELLERUP, S.U.; PARKER, J.E.; ARSCOTT, G.H. Effect of restricted water consuption on broiler chickens. Poultry Science, v.44, p.79-83, 1965.

LLOYD, L.E.; MCDONALD, B.E.; CRAMPTON, E.W. Water and its metabolism. In: LLOYD, L.E.; MCDONALD, B.E.; CRAMPTON, E.W. (Eds.) Fundamentals of nutrition. 2.ed. San Francisco: Freeman Company, 1978. p.22-35.

MACARI, M. Metabolismo hídrico da poedeira comercial. In: SIMPÓSIO TÉCNICO DE PRODUÇÃO DE OVOS, 5., 1995, Jaboticabal. Resumos... Jaboticabal: Associação Paulista de Avicultura, 1995. p.109-131.

MARKS, H.L. Role of water in regulating feed intake and feed efficiency of broilers. Poultry Science, v.60, p.698-707, 1981.

NATIONAL RESEARCH COUNCIL - NRC. Nutrient requeriments of domestic animals. 9.ed. Washington, D.C.: 1994. 153p.

NILIPOUL, A.H.; BUTCHER, G.D. Water: the cheap, plentiful and taken for granted nutrient. World Poultry, v.14, p.26-27, 1998.

NÚÑEZ, M.C.; BUENO, J.D.; AYUDARTE, M.V. et al. Dietary restriction induces biochemical and morphometric changes in the small intestine of nursering piglets. Journal of Nutrition, v.126, p.933-944, 1996.

PENZ, A.M.; VIEIRA, S.L. Características nutricionais da dieta de primeira semana de pintinhos. In: SIMPÓSIO GOIANO DE AVICUlturA, 2002, Goiânia. Anais... Goiânia: Simpósio Goianio de Avicultura, 2002. p.21-27.

STATISTICAL ANALYSIS SYSTEM - SAS. Statistic analysis system. Painless Windows, a handbook for SAS users. 2.ed. Guelph: Jodie Gilmore: 2001. 61p.

YU, M.W.; ROBINSON, F.E.; CLANDININ, M.T. et al. Growth and body composition of broiler chickens in response to different regimens of feed restriction. Poultry Science, v.69, p.2074-2081, 1990.

ZULKILFI, I.; SIEGEL, P.B. The good and the bad of stress. Arbor Acress: Glastonbury, 1995. p.18-23. (Service Buletim). 